\title{
PROBIOTIC FUNCTIONAL FOOD VS DRUGS: IMPACT OF INDIAN REGULATORY STATUS ON DESIGN OF QUALITY CONTROL GUIDLINES FOR PROBIOTICS
}

\author{
Available online at www.ijdra.com \\ REVIEW ARTICLE \\ Singh Neetu*, Gupta Manish \\ School of Pharmacy, Lloyd Institute of Management and Technology \\ Greater Noida (Delhi/NCR), India. \\ *Corresponding Author's E-mail: neetusinghkumar@yahoo.in
}

\begin{abstract}
Probiotic now a day's generally utilized all around the globe because of headway as a part of the relationship in the middle of nourishment and wellbeing other than their promising helpful advantages and irrelevant reactions. Indian probiotic industry is accomplishing its pace at relentless rate with open doors for fast development in not so distant future. Indian probiotic business sector is esteemed at US \$310 million in 2011, is required to witness US \$522.8 million by 2018. Presentation of a scope of pharmaceutical probiotic definitions in the business sector further expanded the turnover of probiotic industry. The eventual fate of probiotic sustenance's is notwithstanding encouraging, as current buyers are concerned to keep up their own wellbeing, and expect the nourishment that they eat to be solid and equipped for counteracting ailment. this is the time when Indian regulatory bodies/ authorities should prepare a guideline to evaluate efficacy claims rigorously, and by consumers interested in potential therapeutic and preventive health benefits. The Indian marketplace is a mixed bag of products, some well-defined and properly evaluated in controlled clinical studies and others with unsubstantiated claims of efficacy. Validation of probiotic contents in commercial products is needed to ensure consumer confidence. Probiotics must be identified to the level of strain, must be characterized for the specific health target, and must be formulated into products using strains and doses shown to be efficacious. Several characteristics commonly presumed to be essential to Probiotics, such as human origin and the ability to improve the balance of the intestinal microbiota, are discussed.
\end{abstract}

Keywords: Quality control guidelines', Legislation, Probiotics, Functional food.

\section{INTRODUCTION}

The internationally endorsed definition of Probiotics is live microorganisms that, when administered in adequate amounts, confer a health benefit on the host. Other definitions advanced through the years have been restrictive by specification of mechanisms, site of action, delivery format, method, or host.

Probiotic niche products include ice cream, cheese, candy, and chewing gum, although they do not play a major role in the European marketplace. Sometimes, Probiotics are combined with soy and oat and then are added to cow milk-based probiotic products. Alternatively, entirely oat- or soy-based material is fermented with Probiotics and other cultures. A fairly new and potentially bigger product category includes breast milk substitutes, milks for older babies (i.e. "follow-on" milks), and special infant formulas. Legislation for infant formulas is extremely strict, and strains used in such products must be well documented.

FAO/WHO definition for Probiotics was still relevant, but advised a minor grammatical correction: "live microorganisms that, when administered in adequate amounts, confer a health benefit on the host" (1).

\section{As per FAO/WHO}

- 'Live cultures', traditionally associated with fermented foods, would be outside the framework of probiotic if they were undefined and if there were no proven health benefits associated with them. Traditional fermented foods are great components of a healthy diet, and the microbes associated with them may impart health benefits. But there must be a convincing level of evidence to support their health effects to be considered 'Probiotics'. Note that the yogurt starter bacteria, Lactobacillus bulgaricus and Streptococcus 
thermophilus are considered to be Probiotics due to the evidence that they help alleviate symptoms of lactose maldigestion.

- Undefined, fecal microbiota transplants are not considered to be Probiotics.

- New commensals and consortia comprising defined strains from human samples, with adequate evidence of safety and efficacy, are Probiotics (2).

\section{DRUG: Drugs and Cosmetics Act, 1940 \& rules 1945}

(i) all medicines for internal or external use of human beings or animals and all substances intended to be used for or in the diagnosis, treatment, mitigation or prevention of any disease or disorder in human beings or animals, including preparations applied on human body for the purpose of repelling insects like mosquitoes.

(ii) such substances (other than food) intended to affect the structure or any function of the human body or intended to be used for the destruction of 6 [vermin] or insects which cause disease in human beings or animals, as may be specified from time to time by the Central Government by notification in the Official Gazette.

(iii) all substances intended for use as components of a drug including empty gelatin capsules.

(iv) such devices intended for internal or external use in the diagnosis, treatment, mitigation or prevention of disease or disorder in human beings or animals, as may be specified from time to time by the Central Government by notification in the Official Gazette, after consultation with the Board. (3)

\section{FOOD}

Any nutritious substance that people or animals eat or drink or that plants absorb in order to maintain life and growth.

\section{PROBIOTICS}

Probiotics are live microorganisms, which when administered in adequate amounts confer a health benefit on the host. $(1,4)$
The field of Probiotics is developing rapidly as evidenced by expansion of research and increased familiarity of Probiotics to the general public. Over the years the FAO/WHO definition of Probiotics remains applicable to scientific, industrial and regulatory communities, as long as it is interpreted correctly. Examples of misuse of the term exist both in the commercial arena, when the term is used on products with no substantiation of human health benefits, and in the scientific arena, where the term has been used to describe bacterial components, dead bacteria or bacteria with uncharacterized health effects in humans. The clarifications below provide more detailed insight into the correct use of the term "Probiotics." The intent is to enhance precision for basic and clinical research efforts on Probiotics as well as facilitate the work of regulatory bodies concerned with issues of probiotic safety and consumer protection.(4)

\section{PROBIOTIC: Functional food vs. Drug}

The FAO/WHO activities were specifically focused on food uses of Probiotics; however, the definition advanced by this group was sufficiently broad to encompass a range of probiotic preparations and intentions of use. In addition to being a food or a dietary supplement, a probiotic microorganism(s) may be used in drug applications (referred in some instances as a live June 9, 2009 biotherapeutic), microbial feed (animal uses), genetically modified organisms, and live vaccines if administered orally.

Requirements for establishing efficacy and safety for Probiotics are different for the different subcategories for Probiotics. For example, a probiotic used as a drug must not only fulfill the general FAO conditions stipulated above, but also conform with existing national regulations (e.g., US Food, Drug, and Cosmetic Act and EU Directive 2004/27/EC on substances used for treating or preventing disease) and guidelines on good clinical practices. $(4,5)$

\section{Probiotic current status in India}

Sustenance industry of India is one of the problem area for financial specialists. Since the mindfulness about the probiotic and its medical advantages has become immensely among 
Indian populace, interest for probiotic nourishments has increased much notoriety. Indian and multinational organizations are coming into the photo since they entered the Indian sustenance industry in 2007. Indian probiotic business was esteemed at $\$ 2$ million according to 2010 assessments. As per figures discharged by US-based research firm, Frost and Sullivan, in August 2012, probiotic items in India created income of US $\$ 310$ million in 2011. The business sector worth expected to increment up to US $\$ 522.8$ million by 2018 . As of now Milk and matured milk items have $62 \%$ of the piece of the overall industry in probiotic items.

Significant pharmaceuticals organizations have get to be dynamic and are attempting to detail more up to date medications and items, and bundled items like probiotic-based wholesome supplements with exceptional requirements for conditions, for example, lactation, pregnancy, immunodeficiency and so on and items particularly for pediatric and geriatric patients. In India Amul, Nestle and Mother Dairy are contributing a ton to Probiotic dairy items and acknowledgment amongst urban populace is serving to build organizations center to create Probiotics items .

In India, Probiotics are frequently broadly utilized as creature food supplements for dairy creatures like steers, poultry and piggery. Lactobacilli suspension is a case of a probiotic detailing, generally given to pediatric patients in India for wide mixed bag of helpful advantages. $\mathrm{ViB}$ act is the most recent and late expansion to the rundown of Probiotics in India (made out of hereditarily changed Bacillus mesentricus), which goes about as another to B-complex containers. Sporulating lactobacilli are created and are sold with a portion of the anti-microbial arrangements in India. In spite of huge development in most recent 3 years, Indian market still has bigger extent of business accomplishment in not so distant future when contrasted with western nation. $(3,6,7)$

\section{Probiotic categorization across the globe: current status}

Probiotics have now turn into a business merchandise as a result of its much far reaching medicinal services settings and worldwide business sector for these useful sustenance's is developing at a quick pace.

Probiotics are classified under distinctive classifications in diverse nations. They are named diversely as regular wellbeing items in Canada, dietary supplements, drugs, therapeutic sustenance, live biotherapeutic specialists, natural operators according to their planned use in USA, utilitarian nourishment in Japan, China, Malaysia, as sustenance supplement in Sweden, Denmark and Finland, biotherapeutic / pharmaceuticals European nations like Belgium and Germany. Probiotics are not considered as single class fairly subcategorized under diverse classifications and are characterized independently by distinctive nations given in Table 1. The nation shrewd administrative status of Probiotics alongside their classification is as per the following (8):

Table 1: Probiotic categorization across the globe $(1,3,8)$

\begin{tabular}{|l|l|l|l|}
\hline \multicolumn{1}{|c|}{ Country } & \multicolumn{1}{|c|}{ Category } & \multicolumn{1}{c|}{ Definition as per country } & Regulatory body \\
\hline Japan & Probiotics & $\begin{array}{l}\text { The live micro-organisms which when } \\
\text { administered in adequate amounts confer } \\
\text { a health benefit on the host. }\end{array}$ & FAO/WHO \\
& $\begin{array}{l}\text { Functional } \\
\text { foods and }\end{array}$ & $\begin{array}{l}\text { As per Japanese system, these products } \\
\text { are in distinct category named as Food } \\
\text { for Specified Health Use, with a specific } \\
\text { regulatory approval process separate } \\
\text { from food fortified with vitamins, } \\
\text { minerals, and dietary supplement not } \\
\text { carrying FOSHU claims. }\end{array}$ & MHLW, FOSHU \\
Nutraceuticals & $\begin{array}{l}\text { Nutraceuticals are defined as parts of a } \\
\text { food or whole food that have any }\end{array}$ & \\
\hline \hline
\end{tabular}




\begin{tabular}{|c|c|c|c|}
\hline & & $\begin{array}{l}\text { medical or health benefit, including the } \\
\text { prevention and treatment of disease. } \\
\text { Vitamins, minerals and herbal } \\
\text { supplements are considered under this } \\
\text { category. }\end{array}$ & \\
\hline Europe & $\begin{array}{l}\text { Functional } \\
\text { foods }\end{array}$ & $\begin{array}{l}\text { A food that beneficially affects one or } \\
\text { more target functions in the body beyond } \\
\text { adequate nutritional effects in a way that } \\
\text { is relevant to either an improved state of } \\
\text { health and well-being and/or reduction } \\
\text { of risk of disease. } \\
\text { It is consumed as part of a normal food } \\
\text { pattern. It is not a pill, a capsule or any } \\
\text { form of dietary supplement. }\end{array}$ & FUFOSE \\
\hline China & $\begin{array}{l}\text { Functional } \\
\text { foods }\end{array}$ & $\begin{array}{l}\text { Functional food is defined as a food that } \\
\text { has special health functions or is able to } \\
\text { supply vitamins or minerals and has the } \\
\text { capability to regulate human body } \\
\text { functions. }\end{array}$ & SFDA \\
\hline Brazil & $\begin{array}{l}\text { Functional } \\
\text { foods }\end{array}$ & $\begin{array}{l}\text { Functional foods constitute items to } \\
\text { which health ingredients are added due } \\
\text { to which have specific physiological } \\
\text { function and/or are enhanced with added } \\
\text { ingredients not normally found in the } \\
\text { product, providing health benefits } \\
\text { beyond their nutritional value. }\end{array}$ & ANVISA \\
\hline $\begin{array}{l}\text { New-Zealand } \\
\text { and Australia } \\
\text { foods }\end{array}$ & Functional & $\begin{array}{l}\text { Functional foods are products which are } \\
\text { supposed to serve physiological roles } \\
\text { beyond the provision of simple nutrient } \\
\text { requirements. }\end{array}$ & FSANZ \\
\hline \multirow[t]{4}{*}{ USA } & $\begin{array}{l}\text { Dietary } \\
\text { supplements }\end{array}$ & $\begin{array}{l}\text { Dietary supplements are intended to } \\
\text { supplement the diet; containing one or } \\
\text { more dietary ingredients (including } \\
\text { vitamins; minerals; herbs or other } \\
\text { botanicals; amino acids; and other } \\
\text { substances) or their constituents and also } \\
\text { to be taken by mouth as a pill, capsule, } \\
\text { tablet, or liquid; and is labeled on the } \\
\text { front panel as being a dietary } \\
\text { supplement. }\end{array}$ & DSHEA \\
\hline & Drugs & $\begin{array}{l}\text { Drug is an article intended for the cure, } \\
\text { mitigation, treatment, diagnosis, or } \\
\text { prevention of disease }\end{array}$ & FDA \\
\hline & $\begin{array}{l}\text { Biological } \\
\text { products }\end{array}$ & $\begin{array}{l}\text { Biological product is a product } \\
\text { containing a virus, serum, or toxin } \\
\text { applicable to the prevention, treatment, } \\
\text { or cure of a disease. }\end{array}$ & BLA \\
\hline & Medical food & $\begin{array}{l}\text { Medical food are those products } \\
\text { intended for external use in the dietary }\end{array}$ & FDA \\
\hline
\end{tabular}




\begin{tabular}{|c|c|c|c|}
\hline & $\begin{array}{l}\text { Live } \\
\text { biotherapeutic } \\
\text { agent }\end{array}$ & $\begin{array}{l}\text { management of a disease or condition } \\
\text { for which distinctive nutritional } \\
\text { requirements have been established by } \\
\text { medical evaluation and is formulated to } \\
\text { be administered under the supervision of } \\
\text { a physician } \\
\text { Live biotherapeutic agent is a biological } \\
\text { product (1) contains live organisms, such } \\
\text { as bacteria; (2) is applicable to the } \\
\text { prevention, treatment, or cure of a } \\
\text { disease or condition of human beings } \\
\text { and (3) is not a vaccine. }\end{array}$ & FDA \\
\hline India & $\begin{array}{l}\text { Functional } \\
\text { foods, drugs }\end{array}$ & $\begin{array}{l}\text { Food that has physiological functions, } \\
\text { including regulation of biorhythms, the } \\
\text { nervous system, the immune. }\end{array}$ & FSSA, PFA, FDA \\
\hline Malaysia & $\begin{array}{l}\text { Functional } \\
\text { Foods }\end{array}$ & $\begin{array}{l}\text { Currently no official definition available } \\
\text { for functional food products in Malaysia. }\end{array}$ & $\begin{array}{l}\text { FSQD, the Drug } \\
\text { Control Authority, } \\
\text { NPCB and the } \\
\text { Committee for the } \\
\text { Classification of } \\
\text { Food-Drug Interface } \\
\text { Products. }\end{array}$ \\
\hline Canada & $\begin{array}{l}\text { Natural health } \\
\text { products }\end{array}$ & $\begin{array}{l}\text { It is defined as a substance, or a } \\
\text { combination of substances, a } \\
\text { homeopathic medicine or a traditional } \\
\text { medicine, that is intended to provide a } \\
\text { pharmacological activity or other direct } \\
\text { effect in: Diagnosing, treating, } \\
\text { mitigating or preventing a disease, } \\
\text { disorder or abnormal physiological state } \\
\text { or its symptoms in humans; Restoring or } \\
\text { correcting organic functions in humans; } \\
\text { or Modifying organic functions in } \\
\text { humans, such as modifying those } \\
\text { functions in a manner that maintains or } \\
\text { promotes health. }\end{array}$ & $\begin{array}{ll}\text { Natural } & \text { Health } \\
\text { Products } & \\
\text { Directorate } & \end{array}$ \\
\hline
\end{tabular}

\section{Required Attributes of Probiotics}

Regularly, suspicions are made about systems of activity and the "key" qualities of Probiotics on the premise of supposition more than thorough science. Case in point, it is normally stipulated that Probiotics must stick to intestinal cells. Then again, information that bolster adherence of Probiotics are for the most part gotten from in vitro tests, which have constrained consistency for the in vivo circumstance, and must be accommodated with the way that, as a rule, Probiotics hold on just transient in the host in the wake of sustaining has halted. The way of the relationship of Probiotics with the epithelial cell surfaces or mucous layer stays to be resolved.

Despite the fact that it frequently proposed that Probiotics for human utilization must be of "human cause," a few strains that are not typically confined from people have been demonstrated to be successful Probiotics (e.g., strains of the species Bifidobacterium animalis), which discredits this necessity.

The announcement that Probiotics "enhance the equalization of microflora" is regularly made. Be that as it may, it is not clear what this declaration 
means or how is it quantified. Probiotics have been indicated to adjust populaces or exercises of colonizing microorganisms, however does this relate to an "enhanced equalization"? Enhanced offset is frequently compared with expanded fecal levels of lactobacilli or bifido bacteria. This is a measure not of parity but rather of fecal microbiota adjustment. Since no logical agreement exists on the arrangement of a "solid microbiota," the wellbeing ramifications of such microbiota modifications stay indistinct. Besides, it is hard to quantify intestinal microbiota; fecal microbiota is not equal to intestinal microbiota, and luminal microbiota is not equal to epithelial microbiota. Probiotics might, indeed, encourage an arrival to typical status after an irritation of the microbiota (e.g., due to the utilization of anti-microbials or disease) or may diminish the level of progress summoned by such difficulties. This capacity all the more nearly backings the idea that Probiotics can enhance the equalization of microbiota. A couple of studies have measured a probioticupgraded come back to benchmark levels after anti-infection use in people. The idea of probiotic-impelled enhanced offset of microbiota would profit by further study.

At the point when probiotic strains are chosen, characteristics vital for viability and mechanical capacity must be evaluated. Since the scope of focuses for in vivo capacity is wide, traversing oral, stomach, respiratory, intestinal, vaginal, and invulnerable capacities, it would be an overwhelming undertaking to add to a rundown of attributes needed for every single probiotic capacity. Fundamental starting portrayal of strain character and scientific categorization ought to be led, trailed by assessment with accepted tests both in investigations of creature models and in controlled studies in the objective host. In vitro tests are often directed that have not been turned out to be prescient of in vivo capacity. Mechanical vigor should likewise be resolved, for example, the strain's capacity to be developed to high numbers, thought, settled, and consolidated into a last item with great tactile properties, if appropriate, and to be steady, both physiologically and hereditarily, through the end of the timeframe of realistic usability of the item and at the dynamic site in the host. Appraisal of security can likewise be a test, since components, for example, chain length and damage may challenge the common evaluation of settlement framing units, and in vivo capacity.

A reasonable approach for manufacturers marketing a product that contains a probiotic is to use guidelines established by a working group convened jointly by the Food and Agriculture Organization of the United Nations and the World Health Organization, which include the following.

1. Proper identification to the level of strain of all Probiotics in the product, with deposit of all strains in an international culture collection

2. Characterization of each strain for traits important to its safety and function

3. Validation of health benefits in human studies, including identification of the quantity of the microorganism required to provide the benefit

4. Truthful and not misleading labeling of efficacy claims and content through the end of shelf life

\section{Quid lines needed for Probiotics in India}

It is frequently misquoted that probiotic items are unregulated. Obviously, the FDA has administrative power over probiotic items and directs makers' obligations, including the marking and wellbeing of these items, whether in nourishment, supplement, or medication structure. Of note, on 24 August 2007, the FDA issued regulations that oblige current great assembling practices for dietary supplements to be staged in throughout the following couple of years. In spite of the fact that these regulations don't address check of viability cases, ideally they will enhance the compositional quality (personality, immaculateness, and quality) of probiotic supplements in the INDIAN market. In any case, producers of nourishments and supplements are not needed to get premarket regard of cases of adequacy or security. By and by, the FDA has never tested the marking or wellbeing of a probiotic product except in situations where the item is spoken to as a medication (i.e., to treat, cure, forestall, relieve, or analyze malady) and needs approbation as a medication. Generally, these cases result from mistaken item naming by producers that were 
meaning to market a dietary supplement. Absence of significant FDA oversight of cases of viability makes it troublesome for shoppers to recognize probiotic items that are legitimately figured and named from those that are most certainly not. $(7,9)$

\section{CONCLUSION}

The field of Probiotics is developing rapidly in India and everywhere throughout the globe, as is confirm by the expanding enthusiasm of industry, buyers, and specialists. As experts grasp this blossoming range, they have to approach it in a way that will guarantee that item details and interchanges about these items are done mindfully and with the essential target to advantage customers. Both the science and its confinements ought to be corresponded with accuracy. Uncalled for utilization of the expression "probiotic" and inability to perceive the significance of the measurement specificity and strain specificity of impacts is a worry. There is an extraordinary requirement for controlled studies in people to further record the medical advantages of Probiotics as a component of the human eating routine. Vital target bunches for such studies incorporate solid individuals, individuals at hoisted danger for adding to an illness, and individuals hunting down dietary-administration strategies to control side effects. Every one of these gatherings would profit by openly supported exploration of Probiotics as nourishments or supplements. Probiotics could likewise be concentrated on for utilization as medications.

The accompanying experimental suggestions and administrative proposals need as under:

(i) To be termed a probiotic, the smaller scale life form must have the capacity to give characterized medical advantages on the host, in the genuine item that will be made accessible to people.

(ii) GMP (Good manufacturing practices) must be applied in terms of quality control, shelf-life conditions established, and the labeling is made clear to include minimum dosage and verifiable health claims. (iii) The regulatory status of Probiotics as a component of foods should be established on an international level.

(iv) The regulatory framework to be established should include issues related to Probiotics, such as efficacy, safety, labeling, fraud and claims.

(v) Probiotic products shown to confer defined health benefits should be permitted to describe these health benefits.

(vi) Surveillance systems should be put in place to record and analyse any adverse events associated with Probiotics in food. These systems should include trace-back and postmarketing surveillance and they should also monitor the long-term health benefits of probiotic strains.

\section{ACKNOWLEDGEMENT}

I'm thankful to my Guide Dr. Manish Kumar Gupta, Professor, School of Pharmacy Lloyd Institute of Management and Technology for providing necessary guidance and support for writing this Article. The authors also acknowledge affiliation with Raj Kumar Goel Institute of technology for B. Pharm degree.

\section{CONFLICTS OF INTEREST}

Author declares that there are no conflict of interest in this work.

\section{REFERENCES}

1. Food and Agriculture Organization of the United Nations (FAO) [Internet]. FAO; 2001 [cited 2015 Jun 05]. Available from:

http://www.who.int/foodsafety/publications/fs_manag ement/en/Probiotics.pdf

2. Food and Agriculture Organization of the United Nations (FAO) [Internet]. FAO, food safety and quality; 2001 [cited 2015 Jun 05]. Available from: http://www.fao.org/food/food-safety-quality/a-zindex/Probiotics/en/

3. Central Drugs Standard Control Organization (CDSCO) [Internet]. The Drugs and Cosmetics (Amendment) Act, 1995 (71 of 1995); [cited 2015 Jun 05]. Available from:

http://www.cdsco.nic.in/writereaddata/Drugs\&Cosme ticAct.pdf

4. FAO Food and Agriculture Organization of the United Nations [Internet]. Rome: Food and nutrition paper 85; 2006 [cited 2015 Jun 05]. Available from: ftp://ftp.fao.org/docrep/fao/009/a0512e/a0512e00.pdf

5. FAO/WHO. Report of a joint FAO/WHO expert consultation on guidelines for the evaluation of 
Probiotics in food [Internet].London, Ontario, Canada: FAO/WHO:2002 May 1 [cited 2015 Jun 05].

Available from:

ftp://ftp.fao.org/es/esn/food/wgreport2.pdf

6. Morelli L, Capurso L. FAO/WHO Guidelines on

Probiotics: 10 Years Later. Journal of clinical gastroenterology [Internet]. 2012 Oct [cited 2015 Jun 05]; 46 (suppl 1):p s1-s2. Available from:

http://journals.lww.com/jcge/Citation/2012/10001/FA

O_WHO_Guidelines_on_Probiotics_10_Years_Late r.2.aspx

7. Narayanan R. Current legislations on Probiotic products. Journal of agriculture science [Internet]. 2013 Apr [updated 2015 Jun; cited 2015 Jun 06]; 1(2):18-24. Available from:

http://www.accessinterjournals.org/jas/PDF/2013/AP RIL/NARAYANAN.pdf

8. Arora M, Baldi A. Publication of India association of medical microbiologist. Indian journal of medical microbiology [Internet]. 2015 Feb [cited 2015 Jun 06]; 33(Supplement 1): S2-10. Available from: http://www.researchgate.net/profile/Dr_Ashish_Baldi/ publication/272078022_Regulatory_categories_of_Pr obiotics_across_the_globe_A_review_representing_e xisting_and_recommended_categorization/links/54ed c39a0cf25da9f7f22b6d.pdf

9. Science daily. FDA must find regulatory balance for Probiotics [Internet]. Science daily; 2013 Oct 13 [updated 2015 Jun; cited 2015 Jun 07]. Available from:

http://www.sciencedaily.com/releases/2013/10/13101 7144630.htm 